\title{
Online Education as an Opportunity Equalizer: The Changing Canvas of Online Education
}

\author{
Debra Black $^{1}\left(\right.$ Charmaine Bissessar $^{2} \cdot$ Mehraz Boolaky $^{1}$
}

Received: 5 September 2018 / Accepted: 8 April 2019 / Published online: 16 April 2019

(c) The Author(s) 2019

\begin{abstract}
Unique in its diverse cross-section of sources, this review article is a philosophical study towards the future role of online university education. Set within the realistic context of the external forces affecting higher education, it bridges the gap between the perspective of industry and that of higher education. We posit that online education is an opportunity equalizer, positioned to help citizens of lesser developed economies form and upskill to compete in employability with those of developed countries. Both the individuals and the economies of these countries benefit. The purpose of this article is to overview the main factors influencing the ability for higher education to provide this opportunity. Possible challenges are illuminated in the context of the real lived experiences of students. A wide range of sources are canvassed, explaining the external environment within which educational systems and the university exist. Rather than providing answers, this article raises pertinent questions with an understanding of higher education's current state of flux.
\end{abstract}

Keywords Online education · Educational leadership · International education · Emerging markets $\cdot$ EHEA $\cdot$ Globalization

\section{Introduction: Begin in the Future}

Twenty-first century globalization has been the 'game changer' in commerce and, thus, higher education. As economic powers shift and fluctuate, cultures change. Through disruptive technology we have experienced, for the first time in history, a somewhat global millennial cohort who hold a shared sense of the largeness of the world and their self-empowerment to be active citizens in it. This perspective as a citizen of the world is still culturally-bound and mitigated, being stronger in

\section{Debra Black}

debra.black@online.liverpool.ac.uk

1 University of Liverpool Management School Online Graduate Studies, Liverpool, UK

2 University of Roehampton, London, UK 
cultures historically freer in governance and with cultural values of individualism. Yet, it permeates all societies to varied extents (Glenn 2000). Metaphorically, blinders are being shed and vision extended to a peripheral view of the world, and how the individual now fits into that. The citizen of the world no longer resides solely in the countries known to be the economic powerhouses.

Historically, for university higher education, the universities in developed economies have been the drivers in developing and delivering education. This includes partnership with educational institutions and governments in lesser developed economies (Hennessy et al. 2010). It is in developed economies where the greatest demand has been placed for education. In the past, undeveloped and underdeveloped markets have carried too much risk for most corporations to enter. Thus, while these territories are not unknown to the world, their economic opportunity has been largely untouched until this century, which brought a shift in market development and with it, economic power.

The future economic growth is recognized to be in these undeveloped (Frontier) and underdeveloped (Emerging) markets. And while economists and other experts do not agree on a precise listing designating these markets, there is a general set of characteristics about them. They tend to have (although not absolute) poor infrastructure, unreliable technology (creating a digital divide), governance that does not support or sustain equitable opportunities amongst citizens, corruption, and, now in more recent years, increased violence (Shenglin et al. 2017).

Moreover, this growth in these markets will increase demand for an educated populace in order to maximize human resources to economic output. Meanwhile, in recent years, higher education in developed economies has played an increasing role in partnering with industry and government to determine future workforce needs for which the students of today are to be prepared. In the twenty-first century, this has evolved into employability being a formal purpose of higher education such as in Europe (European Higher Education Area) and the United States (e.g. EQUIP Educational Quality through Innovation Partnerships).

Therefore, higher education is at a crossroads perhaps not previously seen. In developed economies, it is transforming to a market-oriented purpose and approach to the design and delivery of education in order to support economic goals in their own countries (Ferreyra et al. 2017). At the same time, the future demand for higher education will come from underdeveloped countries also seeking industry development and individual employability. Hence, universities, similar to their industry partners, will be competing to exploit these new market opportunities. These will provide the growing revenue streams to offset the increased costs of delivering education in their home countries, particularly given the call by governments in the US and other countries to address rising tuition costs. It also will fulfill their societal call to duty as pressures advance upon universities and industry alike to engage social responsibility.

With this in mind, the university students of the future will come from not just diverse cultures but diverse situations all over the world, with barriers and challenges to be accommodated that are not found in developed economies. Review of expert perspectives ranging from a diverse cross-section of sources provide the context within which this paper analyzes the current state of flux affecting higher 
education and the nature of environments within which future students will attend online studies. The authors posit that in twenty-first century globalization, with pressures from governments and industry, there is a focus on the employability of students rather than their holistic development. It is important for higher education to be prepared to fulfill its duties and responsibilities in both. We also posit that online education, specifically university studies, is the most efficacious medium in which to do so.

\section{Higher Education's Purpose and Role: An Identity Crisis?}

Schwab (2018) opined:

Globally, people are enjoying the highest standards of living in human history. And yet acceleration and interconnectedness in every field of human activity are pushing the absorptive capacities of institutions, communities and individuals to their limits. This is putting future human development at risk (World Economic Forum 2018, p. 5).

With the aforementioned in mind, both eastern and western educational systems historically have had commonality of purpose: to form the individual in virtue, thus, in citizenship, and from this, contributing to the social good (Morton 2016). As a collector of knowledge necessary to do so, the university's role has been both keeper of the knowledge and to pass this knowledge on. In recent centuries, western higher education took on the role of creator of the knowledge as well. However, in the twenty-first century, forces for change which began in the 1990s gelled into a new purpose for the university: employability of students. Along with this has come the implementation of commercial marketing perspectives and techniques into all aspects of delivering education. Governments embracing this have formed new ministries to serve education while reforming or eliminating traditional agencies (Karseth and Solbrekke 2016; Sin et al. 2017).

Assuming universities to have a public-interest purpose, recent views indicate a change has taken place. McElvey and Zaring (2018) posit universities are becoming 'knowledge businesses instead of social institutions' (p. 596) and see the services of universities as knowledge-intensive. Others continue in agreement with this such as Glenna (2017) who, focusing on university scientific research, captures the impact of universities becoming economic and efficiency driven over social institutions. Previously considered serving the public good, higher education as an institution helped to balance the impact of social and cultural change made by economic and political institutions. Historically, the professions maintained within the university emerged "through efforts to generate and preserve non-market norms, even within a capitalist political economy", housing knowledge passed down to future generations (Glenna 2017, pp. 1027-1028). This role may be threatened as universities transition into knowledge businesses.

Whether or not one agrees with the purpose of higher education as transitioning from a social institution to a quasi-commercialized one, changes have occurred 
this twenty-first century that have necessitated a rethinking of education delivery. University systems around the world are adopting the marketing approach to delivering educational 'products' to student 'consumers'. Explanations of this are given by Maxwell-Stuart et al. (2018) who found that there is increased satisfaction of students who participate in co-creation of the educational experience. This approach focuses on consumer satisfaction. However, in non-academic commercial industries, the measurement of the product's 'success' is not determined by the transformational growth in character and knowledge of the consumer, whereas it is in education. The nature of higher education as a 'product' renders it unique to all other industries and, thus, any attempts to use commercial measurements such as consumer satisfaction should be taken with great caution. What has been seen is the opposite: focus on satisfaction of student-consumers has become the measurement. This perceived satisfaction risks affirming students in their current states and stages of psychological and moral growth rather than challenging them to a paradigm shift. This consumer satisfaction approach becomes relevant when exploring the millennial students' preparedness and willingness to develop the emotional and cultural intelligences desired by industry, as we will see later in this article. International online university studies have the dynamic to elicit this paradigm shift.

The evolution of the Bologna Process and Copenhagen Process into the European Higher Education Area (EHEA) has resulted in schools at all levels of higher education mapping competencies acquired through studies to meet the competencies necessary for gainful employment. The EHEA stepped beyond this to consider competencies gained by the student through their work alongside those acquired in studies. Further moves were taken in the US by the Obama Administration (USDOE 2014). Thus, when looking to future role and value of online higher education worldwide, we must consider the impact of the internal flux currently experienced by onground institutions, particularly given that almost all online delivery comes from these institutions rather than online-only institutions.

As higher education works through its identity crisis, others continue to posit the importance of education as public space.

The public space of education is broader than public school and brings together institutions, associations and social movements in promoting education. In the school what belongs to the school and in the society what belongs to society. This approach avoids stifling the school by excessive missions, and calls all of society to the educational mission. (Nóvoa 2013, p. 35).

Is 'all of society' accepting its call to the educational mission? Can online international higher education steer clear of this identity crisis of its 'parent' institution and pioneer a clear purpose and role as a global institution?

Furthermore, there is a tremendous movement in education at all levels to create learning opportunities that release individual creativity and strengths rather than forcing these to fit into a mould. Higher education today continues with a centuries-old model of pedagogy in which students learn the theoretical basis for a subject and its applications (Arvanitakis and Hornsby 2016). In recent years, US higher education has experimented with new models that involve training for competencies. Historically, the purpose to university education has been to 
develop a deeper understanding of life and the world. With this switch of focus to competencies rather than understanding, the trend in the last century to develop metacognition and higher order thinking has devolved into emphasis on one's ability to form and articulate an opinion. Meanwhile, the work of the European Higher Education Area (EHEA) addressed as necessary the areas of "knowledge, skills and attitude" (Gomez et al. 2017, p. 2195). Attitude perhaps is the crux of the current situation. As universities in developed economies strive to engage the 'student-consumer', will the university be forming the twenty-first century student-citizen of the world, or will the student be forming the university?

While online education has always served a mature working adult population, the current and future population is the younger millennial generation. More than any previous generation, the Millennials are found to have an external locus of control resulting in an attitude of academic entitlement and an expectation that the instructor is responsible for their success. In the university, research has found this generation to also be "grade-oriented" rather than "learning-oriented", desiring the outcome (the grade) exclusive of the experience to attain it (the learning, which ironically the grade represents). This leads to a more frequent negative attitude towards instructors than Millennial students who are "learning-oriented" (Buckner and Strawser 2016, p. 361). Meanwhile, Hosek and Titsworth (2016, citing Head and Eisenberg 2010), found in their studies that "as information literacy findings suggests, millennials find abstract assignments and too much freedom overwhelming (p. 358). A year later, Dziewanowska's (2017) survey of students in Poland (an emerging market) concluded that:

Studying is still considered as an intellectual adventure leading to self-development and adulthood" and yet also found "students do not have the patience to wait and find out how knowledge can be applied, and they need a more direct (and entertaining) presentation of their usefulness in everyday life. (p. 243).

Thus, at the same point in time in which thought leaders of academia endeavor to build programs that develop critical, creative and innovative thinking, lower educational systems and societal culture in the US and elsewhere are producing students incapable of this in both academic preparation and attitude development. The Millennials have difficulty existing with lack of structure, engaging in complex thinking, and making decisions even when the logical thought process is presented to them (Buckner and Strawser 2016; Hosek and Titsworth 2016). Their view of the world, and their expectations of it serving them, arguably differs from that of the entire world with a disparity greater than past generations.

There is great risk to this. In the workplace, organizations experience the product of the educational system. Managers are finding young employees to be responders rather than learners; metacognition is weak (Medina et al. 2017). Entering the workforce in the US and abroad have been students whose studies have engaged self-reflection to the absence of critical thinking; comprehension to the absence of understanding; a self-centered view of the world in a time in which an other-centered view is needed to attain the emotional and cultural intelligence demanded by a global marketplace. The National Task Force on Civic Learning and Democratic Engagement (2012) explained: 
The kind of graduates we need at this moment in history need to possess a strong propensity for wading into an intensely interdependent, pluralist world. They need to be agile, creative problem-solvers who draw their knowledge from multiple perspectives both domestic and global, who approach the world with empathy, and who are ready to act with others to improve the quality of life for all (p. 23).

\section{Underdeveloped Countries: The Educational Markets of the Future}

According to OECD, over half of millennials in its member countries are expected to enter a bachelor degree program, and over $1 / 4$ into a graduate-level program. Growth in demand for education is anticipated in all OECD countries, with significant growth forecasted for China, India, Brazil and Indonesia. The OECD refers to the "exploding demand for tertiary education worldwide" including those who cannot find access in their home country (OECD 2017a, p. 10). Noticeably absent from their research results are underdeveloped countries such as Nigeria with a growing middle-class in a region whose economic activities with other emerging markets (e.g. China) have risen.

With the aforementioned under consideration, two countries have been chosen for study from different continents. Indonesia is an emerging market with expected growth in demand for university studies per the OECD (2017a). Nigeria provides an example of a bursting population and rising middle class that, although its growth is kept in focus by analysts of market economies (Bryan 2016), researchers of higher education overlook these Bottom of the Pyramid (BOP) countries. It is BOP countries that will have the greatest need for online education due to their lack of resources, and many such as Nigeria need it to take advantage of market opportunities. It is in these emerging and BOP countries that higher education, particularly online, has the greatest potential to act as social innovators.

\section{Case of Nigeria: Barriers, Challenges and Access to Higher Education}

Known as the 'blackest country in the world', Nigeria is one of the largest countries in West Africa and has one of the largest populations of youth in the world (World Bank 2017). 50\% of its current population is urbanized, and by 2050 , its population is expected to double to become the fourth most populous country in the world (The World Factbook 2017). In spite of a large percentage of its population having access to improved drinking water and sanitation, there remains a high risk for major infectious diseases. Nearly $60 \%$ of its population is literate; however, $62 \%$ of its population still lives in extreme poverty. Of the $53 \%$ of its population that are employed, $70 \%$ is in agriculture versus $30 \%$ in industry and services. This indicates a population that, while growing in its consumption of consumer products, is not itself participating in the growth of industry and production. With a human development index ranking of 0.527 , Nigeria is considered very low in its promotion of the 
best interests of its people (United Nations Development Program Human Development Index 2016a, b).

Nigeria has 60 universities, of which only nine provide some form of distance learning (NUC 2018). According to the latest UNESCO UIS report, 95,619 Nigerians study abroad for tertiary-level education (UIS n.d.). However, there is no noticeable influx of students from abroad traveling to Nigeria for university studies. The majority of Nigerians in tertiary-level education then are not exposed to the richness of a multi-cultural classroom which an international student body brings.

According to the OECD, violence in Nigeria has increased fourfold since 2008 (OECD West African Studies 2014). Tens of thousands of people have been killed since 2009 by the Boko Haram alone, with ISIS (Islamic State of Iraq and al-Sham) and Ansaru also causing harm (The World Factbook 2017). Transparency International reports Nigeria as remaining one of the more corrupt countries in the world $(148 / 180)$ in spite of talk for several years of plans for systemic change (2017a). In addition to these, the Global Entrepreneurship Monitor (Herrington and Kelley 2012) indicates infrastructure to also be an inhibitor in economic growth and innovation. Governments with institutionalized corruption render it difficult to develop university-industry-government partnerships to further human development, employability and industry growth. Instability of safety and security can render it difficult to physically attend on-ground studies.

Finally, we look at communications infrastructure as a critical piece of the ability for online education to serve Nigeria in the future. Per Internet World Stats, Nigeria has a $50.2 \%$ penetration rate of Internet access, and $8.7 \%$ are Facebook users. Nigeria is aggressively expanding its broadband/Internet capacity having licensed over 400 ISP providers. In the African continent, Nigeria is second only to South Africa for its use of mobile phones which, per The World Factbook, is $81 \%$ of its population (Internetworldstats, n.d.; The World Factbook: Nigeria 2017). It is 9th in the world for the total number of mobile phone users (The World Factbook 2016).

Political turmoil, government interference, war and terrorism, crime, economic recession and poverty are all factors affecting students. In spite of these barriers, Nigerians have the technological infrastructure to invite a deeper use of online higher education and a growing working class that needs it.

\section{Case of Indonesia: Barriers, Challenges and Access to Higher Education}

In contrast to Nigeria, Indonesia is on the fast-track for growth and prosperity. With a score of 0.0689 , Indonesia is considered moderate in its work towards improving the conditions of its people (United Nations Development Program Human Development Index 2016a, b). Indonesia currently boasts nearly 4500 universities (nearly double that of China, although a much smaller population); however, its institutions are generally not listed in worldwide rankings of quality universities (e.g. U.S. News Global Report, ARWU) (Global Business Guide 2018). Efforts have been made for 15 years to improve Indonesia's educational system, and its leaders recognize that further efforts are needed to build human capacity in order to compete globally. (The World Bank 2018b, p. 2). The analyst reports students' learning levels remain lower 
than other countries in the region. This provides a peek into the external forces influencing an EM towards employable skill development through education.

Indonesia is the 4th most populated country in the world and, with that, the 10th largest economy. Programs are in place to assist infrastructure development pertaining to education. Although it has reduced its poverty level by half in the past 20 years, $11 \%$ of its population still lives in poverty and $40 \%$ of Indonesians have sufficiently low income rendering them vulnerable to falling into poverty (The World Bank 2018a). Fifty-five percent of its population is urbanized, and a very significant percentage of the population has access to both improved sanitation and drinking water. In spite of this, the risk of extreme illness remains high as does maternal mortality rates (The World Factbook 2018). For consideration by the educator is how this affects persistence of students as compared to students in developed nations. For example, the common life event of having a baby carries greater risk for these students. Academic progress and class attendance policies formed for western cultures may need reconsideration.

Although $95 \%$ of its population is literate, Indonesia has a $22 \%$ unemployment rate (The World Factbook 2018). Its corruption is ranked by Transparency International as moderate with a score of 96/180 (2017b). Along with corruption and complex regulatory environment, its infrastructure renders it difficult for conducting business (The World Factbook 2018; The World Bank 2018c). Its government has made plans for improvement particularly in generation of electricity. With $86 \%$ of its business taking place in industry and services, and only $14 \%$ in agriculture, Indonesia participates in both production and consumption in the market. Although Indonesia does not have a high degree of terrorism internally, it is the home-base for ISIS and other terrorist groups (The World Factbook 2018). This always presents future risk of control, disruption or even abolition of delivery of online education to its population.

Indonesia is 5th in the world for the number of mobile phone users (The World Factbook 2016), and $49 \%$ of the total population is active with social media accounts, with YouTube and Facebook being most engaged (Statista 2018). However, Freedom House lists Indonesia as only partly free on the Internet with many restrictions and potential threats (Freedom on the Net 2017). The government's Ministry of Education and Culture has approved for 400 universities to offer online courses in 2018, allowing increased access to studies across its archipelagic terrain. Presumably, these programs will be subject to these existing limitations.

\section{The Future Workplace and the Mismatch with Today's Classroom Reality}

If the purpose of higher education is now employability, then we must look to what is truly needed in the twenty-first century marketplace. The studies of several world-renowned consultancies provide clues as to the problem at hand. In a world of ever-increasing knowledge building and sharing, we do not have employees to make use of it. Citing their own Accenture Volatility and Agility study 2014, Accenture found that the skills needed in future leaders are 
problem-solving (78\%), leadership (75\%), communication (73\%) and technology $(73 \%)$. The world's knowledge is growing rapidly, expected to double every 1.2 years. Ironically, 4/5 businesses cannot find labor with the analytical skills needed to interpret this data. "By 2020 there may be a global shortfall of 40 million skilled workers" (Accenture 2016, p. 14). And Deloitte's (2018) Human Capital Trends report found that their survey respondents saw future demand for "complex problem-solving (63\%), cognitive abilities (55\%), and social skills (52\%)" (p. 8).

Deloitte's report warns of the major change to organizations rapidly underway:

Organizations are no longer assessed based only on traditional metrics such as financial performance, or even the quality of their products or services. Rather, organizations today are increasingly judged on the basis of their relationships with their workers, their customers, and their communities, as well as their impact on society at large-transforming them from business enterprises into social enterprises. (p. 2)

External forces upon the organization mean the internal organization must operate differently than the past. And that takes a breadth of characteristics and skills of its workforce to engage in both the internal collaboration as well as engage with people and organizations outside of their company. This goes well beyond learning soft skills of articulate communications and pleasant demeanor. It requires right reason and attitude and as we saw above, those are lacking in the formation of younger generations in the US; presumably, elsewhere as well. Deloitte (2018) has found the public will now expect business to be the force "for the broader good" (p. 4). Meanwhile, Gallup's (2015) longitudinal research of management has defined the oft-used word of 'talent' as "the natural capacity for excellence" (p. 15), identifying authentic relationships as an important trait. Here, then requires not only problem-solving and critical thinking, but also universal ethical traits such as integrity (honesty, justice and trustworthiness) and self-sacrificing found as desired in various global studies such as the Project GLOBE leadership study. Traits that were found to be universally undesirable around the world include self-centeredness, malevolence, status conscious, and conflict inducer (Dorfman et al. 2012, p. 5, 15). For a generation raised on 'reality TV', the minds and hearts of many of our future students and workforce have been conditioned into not knowing these distinctions.

Such dispositions are both furthered, and enhanced by, critical thinking (ACARA n.d., p. 2). While studies indicate a desire by industry to have employees formed in critical thinking and increased creativity, the above-described Millennial student is poorly prepared in both ability and attitude to be formed by university studies,. Higher education's movement away from developing the whole person in higher understanding, and to one of developing competencies and measuring comprehension, bridges these students into university programs and then the workplace, but does not truly meet the needs of society for an educated citizenship. International online university studies that are designed to be global in nature (drawing participation across national borders) can best provide the development necessary for the future as well as benefit the economy of lesser developed countries in ways that differ from locally-offered online classes. 


\section{How Online Education Equalizes Opportunity}

\section{Building Cultural Intelligence}

The twenty-first century interconnected global society poses a need for its citizens to be culturally sensitive and gain cultural intelligence (commonly referred to as CQ). The world faces civil wars and terrorism, environmental challenges, economic ripple and domino effects that move more quickly and are farther reaching than past centuries, materialism, and a worldwide epidemic of depression (World Health Organization 2012). Collaborating for meaningful coexistence with those of differing or opposing values and lifestyles is paramount to overcoming these challenges. International online university studies provide opportunity to experience a variety of cultural perspectives in a neutral classroom environment that, when properly managed by faculty, elicit authentic engagement. This engagement challenges students as to their own belief systems and personal biases, driving a reflective process necessary to overcome dissonance and transform cultural knowledge into intelligent and sensitive behavior. A sustainable future depends upon citizens educated in international understanding and cooperation. "Citizens who have never examined any of these issues will be left vulnerable in the face of their long-term consequences" (The National Task Force on Civic Learning and Democratic Engagement, p. 22). International online higher education reaches below the barriers to draw in student-citizens of every social strata. It provides opportunity not only for knowledge development but also that of joining in the connectedness of the world, building contacts and alliances. Whereas in the past, public 'voices' and those holding power may have been limited to a more elite group and higher income status, through technology the field for debate, collaboration and solving of societal issues is leveled and open to be inclusive of all citizens. International online university studies provide students with the readiness for participation in global society.

Common Purpose recently surveyed the cross-cultural acquaintances of 300 respondents to gauge openness to cross-cultural interactions as well as cultural intelligence (CQ). Representing 29 countries (59\% in the UK), results indicated people are more connected today with those of other cultures $(80.5 \%$ has friends from other cultures). They are open to those who speak a language different from their own (79.3\%). However, the nature of these interactions does not lead to a deeper understanding of the other culture. Nearly half (48\%) did not find any personal biases of their own illuminated by these relationships, indicating a lack of introspection upon their cultural differences and personal beliefs. When asked if they feel ashamed for not defending someone who is treated with cultural intolerance, $40 \%$ said never. Furthermore, Pearson (2014) explained:

Without a model to explore their own Cultural Intelligence, and without a platform to meet other students in a more heated and discursive context, students are missing the chance to develop the skills that will allow them to cross cultural boundaries in the future. (p. 3) 
International online education is the vehicle for that. Research has found that intercultural learning occurs through the knowledge construction taking place in discussion forums as well as in working through any conflicts that occur along the way (Student perspectives on intercultural learning from an online teacher education partnership, 2016). With proper institutional policies, curriculum that promotes intentional engagement, faculty trained to lead lively discussions, and students primed for discussion forums that are intended to be conversations rather than bulletin boards, the online classroom provides the cross-cultural interaction necessary to the beginning of $\mathrm{CQ}$ development. Design of discussion forum activities that require cultural reflection, and maintaining the forum as a place of dialogue between students and instructors, can probe conversations to delve deeper into the mystery of cultural practices. This is particularly beneficial to students in lesser developed countries who have only recently been able to overcome the digital divide and participate more fully as global citizens.

\section{Beyond Knowledge Sharing: Participation in Knowledge Creation}

Preparing students to be global citizens comes, in great part, through properly designed and led classroom discussions and activities so as to foster social collaborative knowledge construction. Such collaboration requires students to listen, interpret and analyze the information being shared (Sauro 2016). Taking a critical eye towards ideas and reasoning through the opinions posited creates opportunity for further input into that knowledge base and co-construction with classmates. Wen et al. (2015) posit that: "educators must foster and develop an "affinity space" or "community of practice" in order for effective learning to take place (p. 58). The necessity of this is found in IAFOR's research that:

Female students are less likely to speak out in a traditional face to face classroom environment yet in online course discussions are more likely to voice contributions, in turn impacting on perceived deeper learning. (Anderson and Haddad 2005)" ( Clarida et al. 2015, p. 91).

For on-ground, traditional international education, students live away from their home culture on a university campus in a foreign culture. While the immersion into a foreign culture is valuable, it is not a setting in which the knowledge learned in the classroom is immediately made part of their regular lived existence. Thus, there is value to students engaging in online multi-cultural classrooms from within the lived experience of their own home and culture. Taking their learnings and classroom experiences immediately to friends, families and coworkers, students are further challenged in their beliefs, biases and sensitivities to others, working through and furthering knowledge construction. This knowledge becomes immediately implementable in their life. In contrast, students living abroad attending on-ground studies are extracted from their lived reality into a temporary location (the on-ground campus), build knowledge in a hypothetical setting which is stored in memory for later recall. They do not have opportunity to immediately put it to use, test it within their everyday life and in the process further construct understanding. In this way, 
international online university studies may be uniquely positioned to meet the needs of industry for employees skilled in problem-solving, critical thinking and cultural intelligence.

\section{Circular Benefit to Students via Economic Growth and Societal Impact}

It has been long known that unemployment is lowered and employment rises based on the level of education achieved. While the increase in employment is notable for those with undergraduate degrees or higher, the increase in earning potential is significant (OECD 2017a, b). For the society, a major study of the locations of 15,000 universities by the London School of Economics found significant correlations between the presence of the university to its local economy. Doubling the number of universities per capita showed an increase of $4 \%$ in GDP per capita (Valero and Van Reenen 2016, p. 1). The research also indicates the economic growth expands beyond the location of the university, into contiguous regions and even the entire country (ibid p. 18).

A study by the National Institute of Economic and Social Research found that university graduates contribute economically to their region in multiple ways:

- GDP per employment hour increased from 1982 to 2005 in all countries;

- The share of employment with tertiary education also increased from 1982 to 2005 in all countries; and

- A $1 \%$ increase in the share of the workforce with a university degree raises the level of long-run productivity by $0.2-0.5 \%$. (Holland et al. 2013, p. 5)

This research focused on the 'top 100 universities in the world' located in 15 developed economies. Online education has the ability to bring this advantage into areas where on-ground institutions are sparse due to the numerous challenges germane to their situational existence. The online delivery medium provides ways of diverting many of these barriers resulting in an ongoing injection of graduates into their local economy. Online programs delivered from a developed economy into an underdeveloped one does not provide the 'presence' and subsequent spillover effect that an on-ground institution gives. Nevertheless, the building up of human capacity and innovation that occurs with on-ground institutions ( Valero and Van Reenen 2016) is an outcome of the development of its people rather than facilities, and online education has potential for further reach as it is not inhibited by physical constraints.

As an outsider to the local cultural and societal strata, online education can serve as a disrupter to barriers that seem impenetrable. Research by Lopes (2017) illuminates the hidden repression of Brazilian students with lower cultural capital:

Students with higher cultural capital and socioeconomic status have habitus more conformable to the university environment. Habitus are acquired dispositions that 'give individuals varying cultural skills, social connections, educational practices, and other cultural resources, which can be translated into different forms of value (i.e., capital) as individual move out into the world' 
(Lareau 2003, 276). Thereby, Reproduction theory suggests that career aspirations and predispositions are highly associated with individual external social conditions. Objective opportunities, which are structurally defined by society, feed the individual's subjectivity and guide future choices, such as students' undergraduate field of study. (Lopes 2017, p. 2356)

We posit that online higher education has potential to introduce students into future career paths with less hindrance from their own personal social standing. This should also reduce the 'undermatching' that occurs subconsciously when students select a lower socio-economic institution or career path. However, it is recognized that to do so, students' experiences may need to envelope forming non-cognitive skills (soft skills) discussed earlier: emotional and cultural intelligence, collaboration and conflict resolution, etc.

US institutions have grown to be knowledge businesses with a favorable societal impact. However, higher education can also be a delivery channel of social innovation (McKelvey and Zaring 2018, p. 596). Historically, universities in developed economies would encourage students to take part in community service and charitable events. With the evolution of Internet technologies and social media, the focus for many universities has become one of bringing social innovation to areas of need through coordination of stakeholders and resources. Providing knowledge-intensive services involves taking an active part in the change or construction of processes needed for delivery, all of which serves the public good. Thus, indirectly, higher education institutions act as 'co-deliverers' of social innovation through their academic engagement with society (McKelvey and Zaring 2018, p. 598). Benefit is seen at the individual level as well as from graduates of university programs who report outcomes that indicate participation as a global citizen such as increased volunteerism, trust in others, and self-perception as actively engaged their society (OECD $2017 \mathrm{a}, \mathrm{b})$. Whereas lower-level education produces students prepared to function in society of the present, higher education prepares students to innovate and create their future. This is in addition to the obvious benefit of developing trained/trainable human capacity within the society (Conway et al., OECD 2010).

\section{Cost of Online Education Decreasing}

Although it is not within the scope of this article to address the many financial considerations to delivering and taking online courses, it remains pertinent to note. Historically, for students in under and undeveloped countries, there was much prestige associated with study abroad. This, however, does not mitigate the value also placed upon the online international program experience in spite of its lack of cultural immersion into a physical location. This is evidenced by the University of Liverpool's amassment of over 12,000 alumni and 8000 students from 160 countries in its graduate programs. Study abroad students face numerous financial and personal challenges unique from domestic on-ground students, such as appropriate housing, employment limitations, integration into the campus and local community, and lack of support (Calder et al. 2016). Online students in international programs avoid these issues. 
Additionally, while online tuition originally was higher priced than its on-ground course counterpart, this has changed in the past decade. In a study of 80 private non-profit two-year colleges within the United States, Ahlstrom (2016) found that $87 \%$ set tuition as equal to their on-ground offerings. Through a review of resource allocation, the University System of Georgia (United States) developed a systemwide cost to deliver online courses at only \$43 per credit hour (Bryan et al. 2018). Wang (2015) conducted a simple review of 103 US university websites and found that not only was online course tuition lower than on-ground counterparts, tuition was on average one-third less. Wang's study found both large and small institutions priced their online studies lower than on-ground tuition, whereas medium-size institutions priced both programs similarly. Finally, "Private educational institutions set significantly lower prices of online courses than public institutions" (Findings, \#4) was an important finding as the reverse of this was true in the early years of online education.

Many, if not most, institutions now engage open educational resources (OER) to reduce student cost. Some institutions, such as University of Maryland University College, have eliminated textbook and material fees altogether in this manner while maintaining a rich and relevant knowledge-base for student learning (University of Maryland University College 2018). Commonly available technologies such as WordPress are often found to be easily accessible overcoming the digital divide in challenged economies, with instructors individually adapting their courses to these more accessible platforms such as smartphones (Van Hook 2018).

In summary, the twenty-first century has brought forth innovation and efficiencies in development and delivery of education through strategies, technologies, business models and strategic stakeholder alliances. This has increased affordability and accessibility of online university education to all populations.

\section{Challenges to Attending Online that Still Exacerbate Access and Persistence}

It appears all pieces of the puzzle are in place to deploy international online university studies across the world and, with it, opportunity to level out economic and social disparities. However, challenges remain such as:

- Mismatch of school policies to reality of students' challenges and barriers, particularly when from a western developed perspective;

- Cultural intelligence of faculty and staff to develop and deliver culturally-relevant and forward-thinking education;

- Lack of freedom to use the Internet in many countries; and

- Governmental interference in personal lives as well as industry development that mitigates availability of digital technologies (the digital divide).

With this in mind, international online universities of the future need to embody the principles of agile organization. Coupled with the ability to be flexible and 
spontaneous, this permits creation of a curriculum centered in developing students' character holistically that remains relevant to the region.

The students themselves may be the challenge as well. We ought not to assume that growing penetration rates of Internet access, mobile phone and social media use result in students from underdeveloped countries being prepared to independently navigate the online environment. When introducing the online course experience in Cambodia, administrators and faculty found:

The course was designed to address the students' minimal level of English language competency and lack of online learning experience. However, it appears our expectation that students could create accounts and learn to independently navigate the online learning platform within a short face to face session may have been overly ambitious. (Crews and Parker 2017, p. 711).

Per IAFOR, younger students are comfortable using social media and technology for consumption but not creation. They are accustomed to consuming it for personal reasons and information gathering (informal learning) but not formal learning which engages critical thinking, constructing of knowledge, and creation of products such as papers (Clarida et al. 2015, p. 98).

All students experience academic stress which can affect motivation and thus affect their success in self-directed learning (SDL) (Heo and Han 2018). Certainly, however, the unique challenges faced by students in lesser developed countries potentially add stressors affecting their SDL. Therefore, preparing and delivering the online course in a manner that promotes their SDL and eliminates potential for unnecessary academic stress (such as miscommunications or lack of guidance) generates further mastery of their SDL.

\section{Conclusion: Back to the Future}

According to Schwab and Brende (2018):

This generation enjoys unprecedented technological, scientific and financial resources, which we should use to chart a course towards a more sustainable, equitable and inclusive future. And yet this is perhaps the first generation to take the world to the brink of a systems breakdown. (World Economic Forum, p. 5)

The world is experiencing a paradigm shift, and higher education is no stranger to it. For example, US higher education continues to be considered the 'envy of the world' (Bell-Rose 2016, p. 2). The Open Doors' study (IIE 2018a) indicates a continued increase in international students attending on-ground within the US, now representing over 5\% of the US college enrollment. Additionally, nearly 3/4 (18/25) of the countries feeding students into it are coming from the underdeveloped markets, the growing economies (IIE 2018b). In contrast to the increase of international students into on-ground US education, the 2018 Babson College study found $<1 \%$ of all online students in US programs are located outside of its borders (Seaman 
et al. 2018). As the 'envy of the world', US educational practices are imported into and adopted by institutions throughout the world. And yet, in online education, these numbers raise questions as to their lack of experiences with international online students, bringing to question whether it should be considered 'the envy of the world' in this online delivery channel. Is there risk of a myopic view being taken towards educational design and delivery, and then being replicated elsewhere?

In recent years, much attention has been placed upon university students' experiences in developed nations. However, we posit that the prototypical student experience of the past is not the model to take forward into the future. The focus should instead grow to one of understanding the students' lived experience. What does it take to 'go to school' when the hurricane season has forced evacuation or seasonal rains lasting months render electricity sporadic at best? When the government, suspicious of the students' online activity due to the multiple password logins required (to college accounts and classroom), disable his/her internet access? When terrorists decimate the students' villages, destroying their laptops holding all of their coursework? When the death of an extended family member requires 2-4 weeks of travel, whereas the university's policies are based on its western culture of nuclear families that only permit four days bereavement leave?

Business and industry can provide models for unique delivery of online education such as through educational consortiums and regional educational cooperatives. Degrees offered through cooperatives of pooled coursework anchored in an NGO or social enterprise allow pooling of resources while bringing in outside expertise that would mitigate the above risks. Proper design and delivery would invite international participation beyond the regional countries involved. An alliance of such cooperatives established in regions throughout the world would permit further sharing of resources and classrooms, expanding the international dynamic.

The development of cultural intelligence is a promise of international online education and a demand of the industry. Online education has the opportunity to develop curriculum and classroom dynamics that challenge the student to uncover and address personal biases so as to develop sensitivity and empathy while maintaining their own belief systems. However, regarding the European Higher Education Area and Bologna Process, Karseth and Solbrekke (2016) posited:

The key point is to design curricula that promote the learning of competencies and skills that are needed in today's and tomorrow's economy. This represents a drift away from longer term needs of the society, such as ensuring for the provision of important centers of knowledge and research, to more immediate work to meet market needs. (p. 221)

Is this shift timely in the 'exploitation' of the higher education 'market' of emerging countries? Or, will it miss on developing the holistic person with the characteristics and virtues needed for global citizenship?

Although globalization is somewhat levelling out economic inequality between countries, the disparity of incomes within societies is viewed as fueling global risks in the future. Automation also is anticipated to negatively affect the labor market, increasing unemployment and adding to this disparity of wealth and income. Risk of military action and economic conflicts are extremely high going forward, coupled 
with a continued conflict between cultures and national identity (World Economic Forum 2018). Polarization across all fronts is the vision of the immediate future. Online education can act as a necessary stabilizer feeding into these globally-interconnected socio-cultural, political and economic systems. But, to enact this effect requires education that goes beyond merely training for the task and psychologically affirming 'student-consumers' in order to maintain their engagement (and tuition revenues). It necessitates a return to developing the whole person for without this, education lacks developing the abilities necessary to move societies out of polarization. Higher education must go beyond speaking of generalizations in their development of programs, using terms such as cognitive and information processing skills, and social and emotional skills. It must differentiate between forming students to exist in a globally-connected world versus forming students into global citizens. Characteristics required in the present and future, such as emotional and cultural intelligence and sensitivity, are other-centered. Metacognition, critical thinking, creativity and understanding all require initiative which cannot thrive in an underlying assumption of entitlement. All of this collectively impacts society:

Norms relating to work are an important part of the implicit contract that holds societies together. If many people's hopes and expectations relating to employment are fraying, we should not be surprised if this has wider political and societal effects. (World Economic Forum 2018, p. 9).

Proper fulfillment of higher education's societal role must first come out of properly conducting its primary role of forming the human person. This paper argues that online higher education has the opportunity to do just that.

\section{Compliance with Ethical Standards}

Conflict of interest The authors declare that they have no conflict of interest.

Ethical Approval The authors' primary study, of which this article is in part, was approved 25-July 2017 by the University of Liverpool Online Research Ethics Committee.

Informed Consent There has been no use of animals in the study, and human participants gave informed consent prior to commencement.

Open Access This article is distributed under the terms of the Creative Commons Attribution 4.0 International License (http://creativecommons.org/licenses/by/4.0/), which permits unrestricted use, distribution, and reproduction in any medium, provided you give appropriate credit to the original author(s) and the source, provide a link to the Creative Commons license, and indicate if changes were made.

\section{References}

Accenture. (2016). Workforce of the Future. London Innovation Centre. Retrieved from https://youtu.be/ W451tsBftDw. 
Ahlstrom, C. (2016). Review of online programming characteristics and pricing at private not-for-profit two year colleges in the United States. Online Journal of Distance Learning Administration, 19(3). Retrieved from http://www.westga.edu.liverpool.idm.oclc.org/ distance/ojdla/fall193/ahlstrom19 3.html.

Arvanitakis, J., \& Hornsby, D. (2016). Universities, the citizen scholar and the future of higher education. London: Palgrave MacMillan. ISBN 978-1-137-53868-0.

Australian Curriculum, Assessment and Reporting Authority (ACARA). (n.d.). Critical and creative thinking. Retrieved from https://www.australiancurriculum.edu.au/f-10-curriculum/generalcapabilities/critical-and-creative-thinking.

Bell-Rose, S. (2016). A path forward for faculty in higher education. American Council on Education Higher Education Today. Retrieved from https://www.higheredtoday.org/2016/12/19/path-forwa rd-faculty-higher-education/.

Bryan, B. (2016). There's a $\$ 56$ trillion market that could be the biggest in the history of commerce. Business Insider. Retrieved from https://www.businessinsider.com/market-could-be-biggest-inhistory-of-commerce-2016-6.

Bryan, C., Leeds, E., \& Wiley, T. (2018). The cost of online education: Leveraging data to identify efficiencies. Online Journal of Distance Learning Administration, 21(2). Retrieved from https ://www-westga-edu.liverpool.idm.oclc.org/ distance/ojdla/summer212/bryan_leeds_wiley212. html.

Buckner, M. M., \& Strawser, M. G. (2016). Me'llennials and the paralysis of choice: Reigniting the purpose of higher education. Communication Education, 65(3), 361-363. https://doi. org/10.1080/03634523.2016.1173715.

Calder, M. J., Richter, S., Mao, Y., Kovacs Burns, K., Mogale, R. S., \& Danko, M. (2016). International students attending Canadian universities: Their experiences with housing, finances, and other issues. Canadian Journal of Higher Education, 46(2), 92-110.

Clarida, B. H., Bobeva, M., Hutchings, M., \& Taylor, J. (2015). Strategies for digital inclusion: Towards a pedagogy for embracing and sustaining student diversity and engagement with online learning. Journal of Academic Education. https://doi.org/10.22492/ije.3.se.06.

Crews, J., \& Parker, J. (2017). The Cambodian experience: Exploring university students' perspectives for online learning. Issues in Educational Research, 27(4), 607-719.

Deloitte Insights. (2018). The rise of the social enterprise: 2018 Deloitte Global Human Capital Trends. Deloitte University Press. Retrieved from https://www2.deloitte.com/content/dam/insig hts/us/articles/HCTrends2018/2018-HCtrends_Rise-of-the-social-enterprise.pdf.

Dorfman, P., Javidan, M., Hanges, P., Dastmalchian, A., \& House, R. (2012). GLOBE: A twenty year journey into the intriguing world of culture and leadership. Journal of World Business, 47, 504518. https://doi.org/10.1016/j.jwb.2012.01.004.

Dziewanowska, K. (2017). Value types in higher education-Students' perspective. Journal of Higher Education Policy and Management, 39(3), 235-246. https://doi.org/10.1080/13600 80X.2017.1299981.

Ferreyra, M., Avitabile, C., Botero Alvarez, J., Haimovich Paz, F., \& Urzúa, Sergio. (2017). At a crossroads: Higher education in Latin America and the Caribbean. Directions in development. Washington, DC: World Bank. https://doi.org/10.1596/978-1-4648-0971-2. License: Creative Commons Attribution CC BY 3.0 IGO. Retrieved from https://openknowledge.worldbank.org/ bitstream/handle/10986/26489/9781464810145.pdf?sequence $=2$.

Freedom on the Net (2017). Retrieved from https://freedomhouse.org/report/freedom-net/freed om-net-2017.

Gallup. (2015). State of the American manager: Analytics and advice for leaders. Gallup, Inc. Retrieved from https:/www.gallup.com/workplace/236594/report-separates-great-managers-rest. aspx.

Glenn, E. (2000). Citizenship and equality: Historical and global perspectives. Social Problems, 47(1), 1-20. https://doi.org/10.2307/3097149.

Glenna, L. L. (2017). The purpose-driven university: The role of university research in the era of science commercialization. Agriculture and Human Values, 34(4), 1021-1031. https://doi.org/10.1007/ s10460-017-9824-6.

Global Business Guide (2018). Global Business Guide: Indonesia. Retrieved from http://www.gbgin donesia.com/en/education/article/2018/indonesia_s_tertiary_education_sector_aiming_highe r_11849.php. 
Gomez, M., Aranda, E., Santos, J. (2017). A competency model for higher education: an assessment based on placements. Studies in Higher Education, 42(12), 2195-2215. https://doi.org/10.1080/03075 079.2016.1138937.

Hennessy, S., Onguko, B., Harrison, D., Angondi, E., Namalefe, S., Naseem, A., \& Wamakote, L. (2010). Developing the use of information and communication technology to enhance teaching and learning in East African schools: Review of the literature. University of Cambridge Centre for Commonwealth Education. Retrieved from https://www.educ.cam.ac.uk/centres/archive/cce/publications/ CCE_Report1_LitRevJune0210.pdf.

Heo, J., \& Han, S. (2018). Effects of motivation, academic stress and age in predicting self-directed learning readiness (SDLR): Focused on online college students. Education and Information Technologies, 23(1), 61-71. https://doi.org/10.1007/s10639-017-9585-2.

Herrington, M., \& Kelley, D. (2012). African entrepreneurship: Sub-Saharan African Regional Report. Global Entrepreneurship Monitor. Retrieved from https://www.gemconsortium.org/ country-profile/93.

Holland, D., Liadze, I., Rienzo, C., \& Wilkinson, D. (2013). The relationship between graduates and economic growth across countries. National Institute of Economic and Social Research. Retrieved from https:/www.gov.uk/government/uploads/system/uploads/attachment_data/ file/229492/bis-13-858-relationship-between-graduates-and-economic-growth-across-countries. pdf.

Hosek, A., \& Titsworth, S. (2016). Scripting knowledge and experiences for millennial students. Communication Education, 65(3), 357-359. https://doi.org/10.1080/03634523.2016.1177844.

IIE. (2018a). Open Doors 2017: Executive summary. Institute of International Education. Retrieved from https://www.iie.org/Why-IIE/Announcements/2017-11-13-Open-Doors-2017-ExecutiveSummary.

IIE. (2018b) Open Doors 2017: Data-Places of origin. Institute of International Education. Retrieved from https://www.iie.org/Research-and-Insights/Open-Doors/Data/International-Students/Place s-of-Origin.

Internet World Stats: Nigeria. Retrieved from https://www.internetworldstats.com/af/ng.htm.

Karseth, B., \& Solbrekke, T. D. (2016). Curriculum trends in European higher education: The pursuit of the Humboldtian University Ideas. Higher Education, Stratification \& Workforce Development. ISBN: 9783319215112.

Lopes, A. (2017). Affirmative action in Brazil: How students' field of study choice reproduces social inequalities. Studies in Higher Education, 42(12), 2343-2359. https://doi.org/10.1080/03075 079.2016.1144180.

Maxwell-Stuart, R., Taheri, B., Paterson, A., O’Gorman, K., \& Jackson, W. (2018). Working together to increase student satisfaction: Exploring the effects of mode of study and fee status. Studies in Higher Education, 43(8), 1392-1404. https://doi.org/10.1080/03075079.2016.1257601.

McKelvey, M., \& Zaring, O. (2018). Co-delivery of social innovations: Exploring the university's role in academic engagement with society. Industry and Innovation, 25(6), 594-611. https://doi. org/10.1080/13662716.2017.1295364.

Medina, M., Castleberry, A., \& Persky, A. (2017). Strategies for improving learner metacognition in health professional education. American Journal of Pharmaceutical Education, 81(4), 78-90.

Morton, J. M. (2016). Unequal classrooms: Online higher education and non-cognitive skills. Philosophical Inquiry in Education, 23(2), 97-113.

National Universities Commission of Nigeria. (2018). Retrieved from https://nuc.edu.ng/.

Nóvoa, A. (2013). Teachers: How long until the future? In M. Flores, A. Carvalho, F. Ferreira, \& M. Vilaca (Eds.), Back to the future: Legacies, continuities and changes in educational policy, practice and research. The Netherlands: Sense Publishing. ISBN 978-94-6209-238-9.

OECD. (2014). An Atlas of the Sahara-Sahel: Geography, Economics and Security. Paris: West African Studies, OECD Publishing. ISBN 9789264222359.

OECD. (2017a). Benchmarking higher education system performance: Conceptual framework and data, enhancing higher education system performance, OECD Paris. Retrieved from www.oecd. org/edu/skills-beyond-school/Benchmarking\%20Report.pdf.

OECD. (2017b). Education at a glance 2017: OECD indicators. Paris: OECD Publishing. https://doi. org/10.1787/eag-2017-en.

Pearson, D. (2014). Are students culturally intelligent?-The results. Common Purpose. Retrieved Aug 27, 2014, from http://commonpurpose.org/blog/archive/are-students-culturally-intelligen t-the-results/. 
Sauro, S. (2016). Student perspectives on intercultural learning from an online teacher education partnership. In S. Jager, M. Kurek, \& B. O’Rourke (Eds.) New directions in telecollaborative research and practice: Selected papers from the second conference on telecollaboration in higher education. Research-publishing.net. https://doi.org/10.14705/rpnet.2016.telecollab2016.493.

Seaman, J., Allen, I. E., \& Seaman, J. (2018). Grade increase: Tracking distance education in the United States. Babson: Babson Research Survey Group.

Shenglin, B., Simonelli, F., Ruidong, Z., Bosc, R., \& Wenwei, L. (2017). Digital infrastructure: Overcoming the digital divide in emerging economies. G20 Insights. Retrieved April 4, 2017, from http://www.g20-insights.org/policy_briefs/digital-infrastructure-overcoming-digital-divid e-emerging-economies/.

Sin, C., Tavares, O., \& Amaral, A. (2017). Accepting employability as a purpose of higher education? Academics' perceptions and practices. Studies in Higher Education. https://doi. org/10.1080/03075079.2017.1402174.

Statista. (2018). Penetration of leading social networks in Indonesia as of 3rd quarter 2017. Retrieved from https://www.statista.com/statistics/284437/indonesia-social-network-penetration/.

The National Task Force on Civic Learning and Democratic Engagement. (2012). A crucible moment: College learning and democracy's future. Washington, DC: Association of American Colleges and Universities. ISBN 978-0-9827850-5-8.

The World Bank. (2017) The World Bank in Nigeria overview. Retrieved from http://www.worldbank. org/en/country/nigeria/overview.

The World Bank. (2018a). The World Bank in Indonesia overview. Retrieved from https://www.world bank.org/en/country/indonesia/overview.

The World Bank. (2018b). The World Bank in Indonesia: Investment-led growth continues. Retrieved from Indonesia: Investment-led Growth Continues.

The World Bank. (2018c). The World Bank: Doing business in Indonesia. Retrieved from http://www. doingbusiness.org/data/exploreeconomies/indonesia.

The World Factbook. (2016) Country comparison: Telephone-mobile cellular. Retrieved from https ://www.cia.gov/library/publications/resources/the-world-factbook/rankorder/2151rank.html\#id.

The World Factbook. (2017). The World Factbook: Nigeria. Washington, DC: Central Intelligence Agency. Retrieved from https:/www.cia.gov/library/publications/resources/the-world-factbook/ geos/ni.html.

The World Factbook. (2018). The World Factbook: Indonesia. Washington, DC: Central Intelligence Agency. Retrieved from https://www.cia.gov/library/publications/resources/the-world-factbook/ geos/id.html.

Transparency International. (2017a). Nigeria Country Profile. Retrieved from https://www.transparen cy.org/country/NGA.

Transparency International. (2017b). Indonesia Country Profile. Retrieved from https://www.trans parency.org/country/IDN.

U. S. Department of Education. (2014). Guidance for competency based education experimental site released. U.S. Department of Education. Retrieved from https://blog.ed.gov/2015/09/guidancefor-competency-based-education-experimental-site-released/.

U. S. Department of Education. (n.d.) EQUIIP U.S. Department of Education. Retrieved from https ://blog.ed.gov/2015/10/educational-quality-through-innovative-partnerships-equip-expandingaccess-to-high-quality-innovative-postsecondary-education/.

UIS. (n.d.) Global flow of tertiary-level students. UNESCO Institute for Statistics. Retrieved from http://uis.unesco.org/en/uis-student-flow.

United Nations Development Programme. (2016a). Human Development Reports: Nigeria. Retrieved from http://hdr.undp.org/en/countries/profiles/NGA.

United Nations Development Programme. (2016b) Human Development Reports: Indonesia. Retrieved from http://hdr.undp.org/en/countries/profiles/IDN.

University of Maryland University College. (2018). About online learning. Retrieved from https:// www.umuc.edu/academic-programs/about-online-learning.cfm.

Valero, A., \& Van Reenen, J. (2016). The economic impact of universities: Evidence from across the globe. London School of Economics, Centre for Economic Performance. Retrieved from http:// cep.1se.ac.uk/textonly/_new/staff/ValeroMimeo2016.pdf.

Van Hook, S. R. (2018). The future revisited: Can global learning still save the world? Online Journal of Distance Learning Administration, 21(1). Retrieved from https://www-westga-edu.liverpool. idm.oclc.org/ distance/ojdla/spring211/vanhook211.html. 
Wang, S. (2015). Online vs. on-campus: An analysis of course prices of U.S. Educational Institutions. Online Journal of Distance Learning Administration, 18(2). Retrieved from http://www.westg a.edu.liverpool.idm.oclc.org/ distance/ojdla/summer182/wang182.html.

Wen, A. S., Zaid, N. M., \& Harun, J. (2015). A meta-analysis on students' social collaborative knowledge construction using flipped classroom model. In 2015 IEEE Conference on e-Learning, e-Management and e-Services (IC3e), Melaka, 2015 (pp. 58-63). https://doi.org/10.1109/ ic3e.2015.7403487

World Economic Forum. (2018). The Global Risks Report 2018. World Economic Forum. Retrieved from http://reports.weforum.org/global-risks-2018/.

World Health Organization. (2012). Depression: A global crisis. World Federation for Mental Health. Retrieved from www.who.int/mental_health/management/depression/wfmh_paper_depression _wmhd_2012.pdf.

Publisher's Note Springer Nature remains neutral with regard to jurisdictional claims in published maps and institutional affiliations. 